\title{
ANALISA KINERJA SYSTEM GLUSTER FS PADA PROXMOX VE UNTUK MENYEDIAKAN HIGH AVAILABILITY
}

\author{
Lalu Zazuli Azhar Mardedi ${ }^{1}$,Ariyanto ${ }^{2}$ \\ ${ }^{1,2}$ Universitas Bumigora Mataram \\ E-mail : ${ }^{1}$ zazuli@stmikbumigora.ac.id, ${ }^{2}$ arikkoso025@gmail.com
}

\begin{abstract}
ABSTRAK
Virtualisasi digunakan sebagai sarana untuk improvisasi skalabilitas dari perangkat keras yang ada. Proxmox Virtual Environment (PVE) dengan jenis hypervisor berbasis open source. PVE dapat menggunakan Network Attached Storage sebagai lokasi penyimpanan berbasis jaringan pada storage GlusterFS yang merupakan sistem berkas terdistribusi. Metodologi penelitian menggunakan Network Development Live Cycle (NDLC) yang memiliki 3 (tiga) tahapan yaitu analysis, design, dan simulation prototyping. Tahap analysis dilakukan pengumpulan data dengan cara studi literatur dan analisa data. Tahap desain dilakukan pembuatan rancangan system jaringan dan ujicoba. Pada tahap simulation prototyping melakukan ujicoba terhadap berbagai skenario dan melakukan analisa terhadap ujicoba Read, Write dan Re-Write. Sistem pada PVE diintegrasikan dengan storage GlusterFS dibuat menggunakan dua server diantaranya server PVE 1 dan PVE 2. Hasil kinerja GlusterFS menunjukkan bahwa kemampuan Read file lebih tinggi dibandingkan dengan Write, dan Re-write pada variasi pengukuran file $1 \mathrm{mb}, 10 \mathrm{mb}$ dan $100 \mathrm{mb}$. Simpulannya GlusterFS dapat di-cluster dengan menggunakan node yang sama dengan PVE Cluster yang dapat menggunakan GlusterFS sebagai penyimpanan tambahan pada PVE. GlusterFS juga mendukung fitur live migration sehingga LXC ataupun VM dapat melakukan live migration dari satu node ke node yang lain dalam keadaan online. Kemampuan write, re-write dan read file pada GlusterFS juga relatif stabil pada pengujian ukuran variasi file.
\end{abstract}

Keywords: Virtualisasi, Proxmox Virtual Environment, Storage Glusterfs, Cluster

\begin{abstract}
Virtualization is used as a means to improve the scalability of existing hardware. Proxmox Virtual Environment (PVE) with hypervisor type based on open source. PVE can use Network Attached Storage as a network-based storage location in GlusterFS storage, which is a distributed file system. The research methodology uses Network Development Live Cycle (NDLC) which has 3 (three) stages, namely analysis, design, and simulation prototyping. The analysis phase is carried out by collecting data by means of literature study and data analysis. The design phase is carried out making the design of network systems and trials. At the simulation stage prototyping tests various scenarios and analyzes Read, Write and Re-Write tests. The system in PVE is integrated with GlusterFS storage made using two servers including the PVE 1 and PVE 2 servers. GlusterFS performance results show that the Read file capability is higher compared to Write, and Re-write in the measurement variations of $1 \mathrm{mb}, 10 \mathrm{mb}$ and $100 \mathrm{mb}$ files. In conclusion, GlusterFS can be clustered using the same node as PVE Cluster which can use GlusterFS as additional storage for PVE. GlusterFS also supports live migration features so that LXC or VM can do live migration from one node to another in an online state. The ability to write, re-write and read files on GlusterFS is also relatively stable in testing file size variations.
\end{abstract}

Keywords: Virtualisasi, Proxmox Virtual Environment, Storage Glusterfs, Cluster

\section{PENDAHULUAN}

Server merupakan sebuah sistem komputer yang bertugas sebagai penyedia layanan untuk client. Server diharapkan dapat selalu berada dalam keadaan aktif dan perangkat lunak dan proses yang ada dalam server berjalan secara normal. Dengan fungsi server yang memberikan layanan kepada client, maka server dituntut untuk mempunyai tingkat availability yang tinggi. Pada zaman teknologi maju seperti sekarang ini server tidak hanya terbatas pada server fisik saja tetapi sudah ada teknologi virtualisasi server. Dengan teknologi virtualisasi kita dimudahkan dalam hal maintenance server, pengadaan fisik server, dan biaya yang dikeluarkan lebih murah.[1] 
Akan tetapi pasti akan terdapat masalah yang dapat menyebabkan server tidak dapat memenuhi tugasnya sebagai penyedia layanan, entah itu sebuah bencana alam atau bencana yang disebabkan human error. Untuk itu perlu adanya disaster recovery untuk mengatasi hal tersebut. Salah satu teknologi dalam virtualisasi yang dapat digunakan dalam perancangan disaster recovery adalah cluster komputer. Cluster komputer merupakan sebuah teknologi dimana terdapat dua atau lebih komputer yang dihubungkan (cluster/clustering) untuk dapat bersamasama mengerjakan tugas yang diberikan. Dengan metode tersebut dapat meminimalisir downtime server dan menambah tingkat High Availability server. Berdasarkan penelitian yang dilakukan dari keseluruhan penelitian para ahli diperoleh nilai availability paling besar mencapai 99,50\% dengan tingkat kestabilan cluster dari sisi CPU utilization dan throughput, sehingga sistem cluster virtual ini dapat menjadi solusi untuk meningkatkan sistem dengan tingkat availaibility yang tinggi.[1]

$$
\text { Untuk management virtualisasi }
$$
dibutuhkan perangkat lunak yang sudah mencapai tahap hypervisor. Untuk bisa melayani secara terus-menerus dibutuhkan suatu layanan server yang dioperasikan pada mesin server virtualisasi tempatnya pada mesin server fisik sehingga bisa melayani jumlah layanan yang banyak seperti data-data penting dari tingkat ketergantungan kinerja dari perusahaan, instansi, atau organisasi yang tinggi terhadap layanan server. [2]

Ketika client ingin memperoleh informasi tentang institusi/organisasi tersebut atau mengakses data, mereka dapat langsung mengakses informasi yang telah disediakan pada sistem yang dimiliki oleh institusi ataupun organisasi tersebut, namun terkadang pada saat mengakses data tersebut, terjadi kegagalan. Kegagalan ini terjadi karena single point of failure, kegagalan di satu titik yang mengakibatkan layanan tidak dapat berjalan semestinya. Misalnya terjadi gangguan pada sistem yang berupa kerusakan komputer, storage, jaringan dan bencana alam. Hal ini akan menghambat proses bisnis dan kehilangan data yang mengakibatkan kerugian pada institusi pendidikan ataupun organisasi lain seperti perusahaan. Salah satu solusi untuk mengatasi masalah di atas adalah dengan menggunakan teknologi Automatic File Replication Cluster High-Availability Storage dengan menggunakan GlusterFS. Dengan teknologi ini bertujuan untuk menangani single point of failure, jadi ketersediaan data dapat terjamin dan sistem dapat berjalan dengan semestinya ketika terjadi kegagalan pada satu titik.[3]

Pemanfaatan memanajemen sistem berkas merupakan salah satu fungsi aplikasi open source GlusterFS (Gluster File System) yang terdistribusi (clustered file-system) dan mampu diskalakan sampai dengan beberapa peta-bytes. Saat ini GlusterFS mampu menggabungkan pengolahan data, disk dan memori dari beberapa modul server kedalam penyimpanan tunggal. Pengujian kinerja dari GlusterFS adalah dengan menggunakan bantuan tools Iozone. Iozone adalah pematok bandingan (benchmarking) yang berguna untuk menganalisis kinerja sistem file dengan parameter yang dianalisa meliputi write, re-write, dan read.[4]

GlusterFS jika ada perubahan konfigurasi dapat diperkenalkan saat filesystem online membuatnya sangat fleksibel dan responsif terhadap beban kerja atau kejadian yang tidak dapat diprediksi.[5]

Menggunakan Virtualisasi Server untuk menghemat biaya dalam menjalankan satu server saja, dengan menggunakan virtual server biaya yang seharusnya untuk membeli hardware yang lain dapat dikurangi, sistem yang berjalan pada perangkat keras yang disediakan oleh mesin server tersebut sudah optimal dan efisien.[6]

Penelitian ini dilakukan menggunakan Vmware WorkStation dan diharapkan dengan adanya penelitian ini dapat memberikan manfaat berupa wawasan dan pengetahuan bagi pengguna yang ingin mengetahui kinerja GlusterFS Storage pada Proxmox VE.[7]

Proxmox adalah sebuah proyek open source yang di kembangkan dan di maintain oleh proxmox server Solutions $\mathrm{GmbH}$ di Jerman. Proxmox memiliki platform virtualisasi open source untuk menjalankan appliance,dan mesin virtual. Proxmox merupakan sebuah distro linux virtualisasi berbasis debian (64 bit) yang mengusung Open $Z V$ dan $K V M$, dengan $K V M$ kita tidak hanya bisa menginstall linux saja akan tetapi operating system windows pun bisa kita instal. Namun yang membuat istimewa dari proxmox adalah kemudahan dalam installasi dan administrasi berbasis web. Beberapa keuntungan 
menggunakan proxmox yaitu, kinerja terbaik, instalasi yang telah dioptimalkan, sehingga lebih cepat, mudahdalam manajemen dan cocok untuk kelas enterprise.[6]

Berdasarkan permasalahan diatas maka untuk menunjang kinerja dari pembuatan data center (media penyimpanan) pada Proxmox VE sangat tepat menggunakan GlusterFS sehingga dapat dipastikan bagaimana kinerja system GlusterFS jika diintegrasikan dengan Promox VE. Gluster file system merupakan sistem berkas terdistribusi yang dapat beroperasi dengan kapasitas petabyte dan mampu menangani ribuan client.

\section{METODOLOGI}

Metodologi penelitian yang digunakan adalah Network Development Life Cycle (NDLC) merupakan sebuah siklus proses

perancangan atau pengembangan suatu infrastruktur jaringan yang memungkinkan

terjadinya pemantauan jaringan untuk mengetahui statistik dan kinerja jaringan. NDLC terdiri dari 6 (enam) tahapan meliputi analysis, design, simulation prototyping, implementation, monitoring dan management.[2]

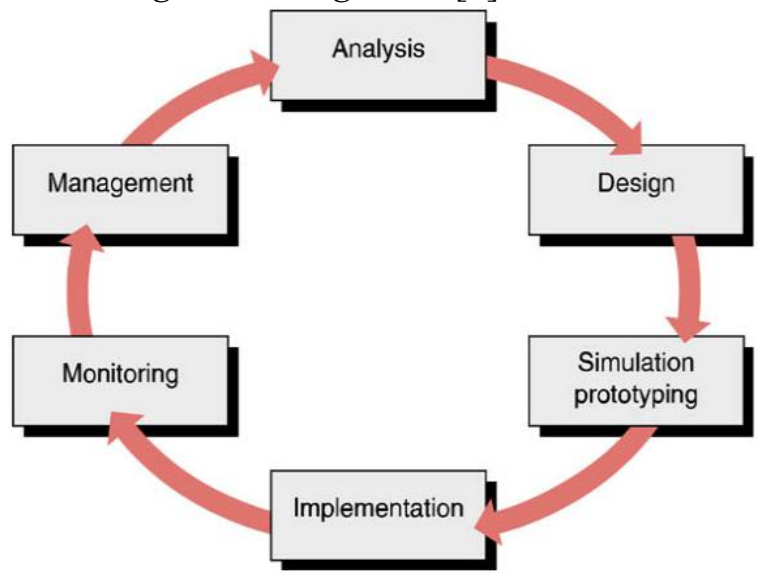

Gambar 1.Network Development Life Cycle

Dari semua tahapan, penulis hanya menggunakan 3 tahapan seperti Analysis, Design, dan Simulation Prototyping.

\section{Tahap Analisys}

a. Pengumpulan Data

Melakukan pengumpulan informasi yang relevan yang didapat melalui literature buku, internet dan karya ilmiah lainnya seperti jurnal ilmiah. Hasil mengumpulkan informasi yang diperoleh dari mempelajari artikel ilmiah yang membahas tentang proxmox dan FreeNAS terdapat pada tabel1.[8]

Tabel 1. Atrikel Ilmiah Tentang Proxmox VE dan Freenas

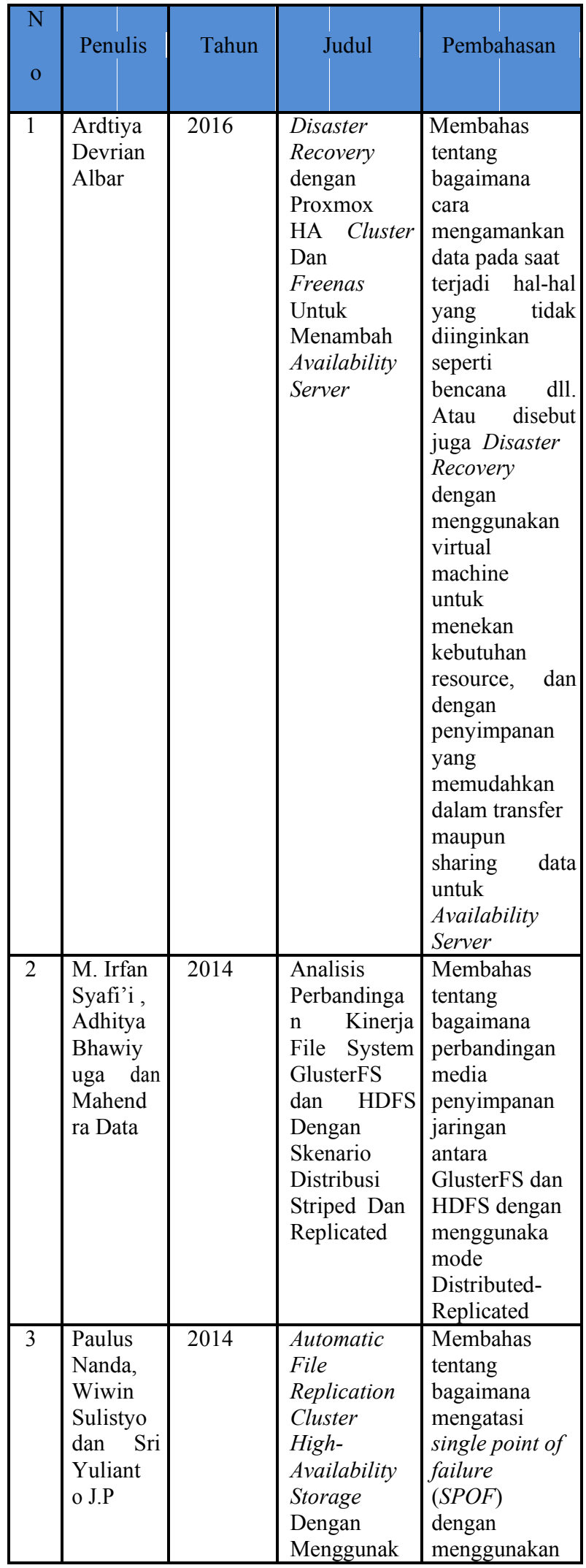




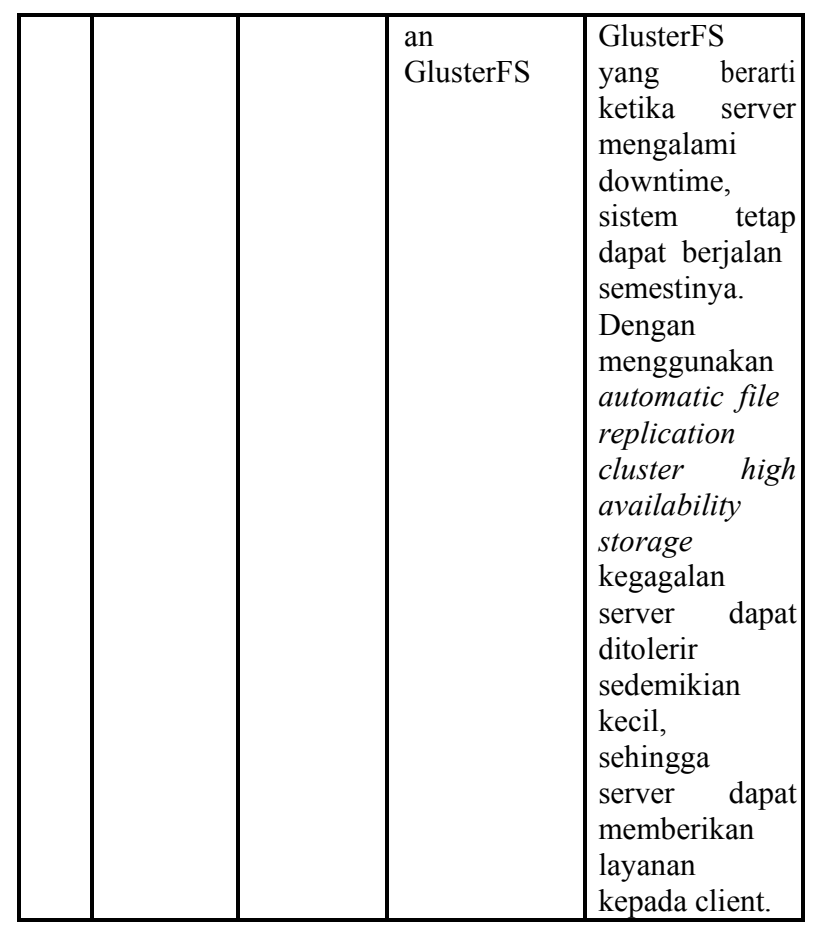

b. Analisa Data

Berdasarkan data yang dikumpulkan dalam literatur sebagaimana yang disebutkan diatas, dapat disimpulkan bahwa:

1. Semua literatur membahas tentang kelebihan menggunakan Network Attcaher Storage (NAS) atau sistem operasi management storage.

2. Proxmox VE mendukung beberapa jenis penyimpanan jaringan

3. Agar dapat menggunakan fitur High Availability minimal dalam satu cluster memiliki lebih dari 1 node.

Dari hasil analisa tersebut mendorong penulis untuk meneliti tentang bagaimana

kinerja dari GlusterFS Storage jika diintegrasikan dengan PVE Clustering untuk menyediakan High Availability (HA).

\section{Tahapan Desain Rancangan}

a. Rancangan Jaringan Ujicoba

Rancangan jaringan ujicoba yang akan dilakukan untuk mengintegrasikan Storage GlusterFS dengan PVE adalah digunakan rancangan ujicoba.

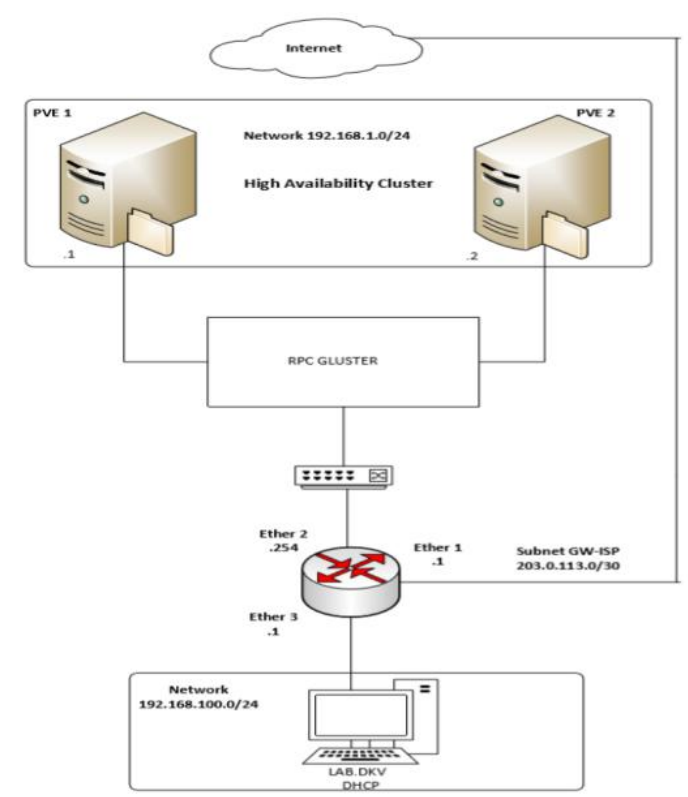

Gambar 2. Rancangan Jaringan Ujicoba

Terdapat2 (dua) server yaitu PVE 1 (node1) dan PVE 2 (node2), 1 (satu) Router dan 1 (satu) PC client. Masing-masing dari server, router dan client tersebut menggunakan alamat IP yang terdapat pada tabel 2 .

\section{b. Rancangan Pengalamatan IP}

Terdapat 3 (tiga) alamat network class $\mathrm{C}$ yang digunakan untuk mengalamati rancangan jaringan ujicoba yaitu 10.10.10.0/24 pada GlusterFS Storage, 192.168.1.0/24 pada ServerPVECluster, dan 192.168.1.0/24 untuk PC Client,sedangkan untuk koneksi internet menggunakan IP Subnet Internet 203.0.113.0/30

Detail alokasi pengalamatan IP per perangkat jaringan yang terlibat pada rancangan jaringan ujicoba, seperti terlihat pada tabel 3.

Tabel 2. Rancangan Pengalamatan IP Address

\begin{tabular}{|c|c|c|c|c|}
\hline $\begin{array}{l}\mathrm{N} \\
\mathrm{O}\end{array}$ & $\begin{array}{c}\text { Nama } \\
\text { Perangkat }\end{array}$ & $\begin{array}{c}\text { Interfac } \\
\mathrm{e}\end{array}$ & Alamat IP & $\begin{array}{l}\text { Subnet } \\
\text { Mask }\end{array}$ \\
\hline 1 & $\begin{array}{l}\text { Router } \\
\text { Gateway }\end{array}$ & Ether 1 & $\begin{array}{l}192.168 .149 \\
.0\end{array}$ & $\begin{array}{l}255.255 .255 \\
.0\end{array}$ \\
\hline & & Ether 2 & 192.168 .1 .0 & $\begin{array}{l}255.255 .255 \\
.0\end{array}$ \\
\hline & & Ether 3 & $\begin{array}{l}192.168 .100 \\
.0\end{array}$ & $\begin{array}{l}255.255 .255 \\
.0\end{array}$ \\
\hline 2 & $\begin{array}{l}\text { Server } \\
\text { Node1 }\end{array}$ & Vmbr0 & 192.168.1.1 & $\begin{array}{l}255.255 .255 \\
.0\end{array}$ \\
\hline 3 & $\begin{array}{l}\text { Server } \\
\text { Node2 }\end{array}$ & Vmbr0 & 192.168.1.2 & $\begin{array}{l}255.255 .255 \\
.0\end{array}$ \\
\hline
\end{tabular}




\section{c. Rancangan Sistem}

Rancangan system $P V E$ dengan GlusterFS Cluster, pada server PVE1 akan dilakukan pengujian Write, Re-Write dan Read menggunakan Iozone Tools. Sistem Cluster ini dibangun menggunakan 2 (dua) server PVE yaitu PVE 1 (node1) dan PVE 2 (node2) dengan nama "DataCenter". Pada server PVE terdapat 2 (dua) jenis media penyimpanan yaitu local dari server PVE dan GlusterFS Storage yang telah diintegrasikan.

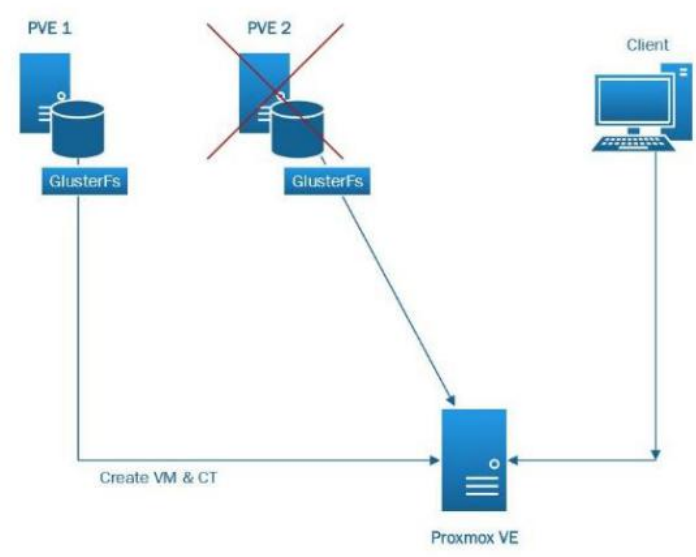

Gambar 3. Rancangan Jaringan Pengujian

Pada Storage GlusterFSterdapat sebuah

hardisk penyimpanan yaitu "/sdb"yang dialokasikan sebagai media penyimpanan utama dari GlusterFS itu sendiri, serta terdapat $L X C$ Container yang dibuat pada PVE (PVE1) dengan CT ID (100) dan VM ID (110) untuk mewakili ujicoba pada penelitian ini, lebih detailnya seperti terlihat pada tabel 3 .

Tabel3.IP Address File VM danCT

\begin{tabular}{|l|l|l|l|l|l|}
\hline $\begin{array}{l}\mathrm{N} \\
\mathrm{o}\end{array}$ & $\begin{array}{l}\mathbf{V M} / \mathbf{C} \\
\mathbf{T}\end{array}$ & ID & $\begin{array}{l}\text { Storag } \\
\mathrm{e}\end{array}$ & $\begin{array}{l}\text { Hostna } \\
\text { me }\end{array}$ & IP Add \\
\hline 1 & $\mathbf{V M}$ & 110 & $\begin{array}{l}\text { Gluste } \\
\text { rFS }\end{array}$ & $\begin{array}{l}\text { VM- } \\
\text { Debian }\end{array}$ & $\begin{array}{l}192.168 .1 .110 \\
/ 24\end{array}$ \\
\hline 2 & $\mathbf{C T}$ & 100 & $\begin{array}{l}\text { Local- } \\
\text { LVM }\end{array}$ & $\begin{array}{l}\text { CT- } \\
\text { Centos7 }\end{array}$ & $\begin{array}{l}192.168 .1 .111 \\
/ 24\end{array}$ \\
\hline
\end{tabular}

\section{Simulation Prototype}

a. Installasi dan Konfigurasi

Pada tahap installasi dan konfigurasi dibagi menjadi beberapa tahap yaitu tahap instalasi dan konfigurasi pada masing-masing perangkat pendukung, ujicoba melalui verifikasi, dan melakukan analisa terhadap ujicoba yang akan dilakukan.

Pada server PVE dilakukan instalasi Proxmox VE versi 5.3 dan ada 1 (satu) tahap konfigurasi meliputi pengalamatan Internet Protocol (IP) pada interface vmbrO dan Vmbrl.

Pada storage NAS dilakukan instalasi GlusterFS versi 3.8 .8 pada masing-masing server Proxmox VE dan pada PC Client akan dilakukan pengalamatan IP secara dinamis atau DHCP pada jaringan interface Ethernet0.

Pada Mikrotik Routerboard yang digunakan sebagai gateway yaitu pengaturan hostname, pengalamatan IP pada interface ether1, ether2, dan ether3, DNS, Default Route, Network Address Translation (NAT), untuk berbagi pakai koneksi internet serta Dynamic Host Configuration Protocol (DHCP) untuk pengalokasian pengalaman IP secara dinamis bagi PC Client.

b. Ujicoba

Tahap ini terdiri dari 2 (dua) bagianya itu verifikasi konfigurasi dan uji coba berbasis skenario. Verifikasi konfigurasi yang dilakukan meliputi 2 (dua) server Proxmox VE, 2 Mikrotik RB951ui-2hndyang difungsikan sebagai router gateway dan PC Client.

Skenario uji coba yang akan dilakukan terdiri dari 8 (delapan) bagian meliputi sebagai berikut:

1. Pembuatan cluster pada server PVE 1 Skenario ini akan dilakukan proses pembuatan cluster di server node 1 .

2. Menggabungkan server PVE 2 ke cluster. Skenario ini dilakukan penambahan server $P V E 2$ sebagai bagian anggota cluster di PVE 1

3. Mengintegrasikan storage GlusterFS Skenario ini cluster PVE akan diintegrasikan dengan GlusterFS Storage.

4. Management storage pada GlusterFS Skenario ini dilakukan pembuatan VM dan CT pada lokasi penyimpanan storage GlusterFS.

5. Live Migration $L X C$ dan $V M$ Skenario ini dilakukan perpindahan VM dan CT dari server PVE 1 ke PVE 2.

6. Instalasi Tools Pengujian Skenario ini dilakukan penginstalan tools pengujian Iozone.

7. Pengujian pengujian Replikasi File Skenario ini dilakukan untuk melihat list file yang di replikasi.

8. Pengujian Write, Re-write dan Read. Skenario ini dilakukan untuk mengukur kecepatan read, write dan re-wrrite pada 
server PVE yang telah diintegrasikan dengan GlusterFS storage.

\section{HASIL DAN PEMBAHASAN}

\section{Hasil Installasi dan Konfigurasi}

Instalasi dan konfigurasi dilakukan pada 2 (dua) server ProxmoxVE yang didalamnya sudah terinstall dan terkonfigurasi GlusterFSStorage,kemudian 1 (satu) buah router Mikrotik difungsikan sebagai gateway internet dan juga client, serta 1 (satu) PC client

yang dilakukan secara virtual pada VmwareWorkstation.

Berikut hasil dari konfigurasi pada masing-masing server dan PC client.

Hasil dari konfigurasi pengalamatan IP PVE pada interface vmbro.

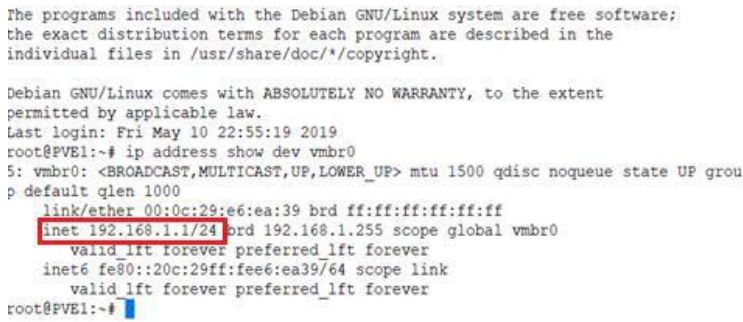

Gambar 4. Konfigurasi IP address pada server PVE interfacevmbr0

Terlihat alamat IP yang digunakan interface vmbro yang terhubung ke subnet server proxmox adalah 192.168.1.1/24.

Hasil installasi dan konfigurasi storage GlusterFSpada PVE 1 dan PVE 2.

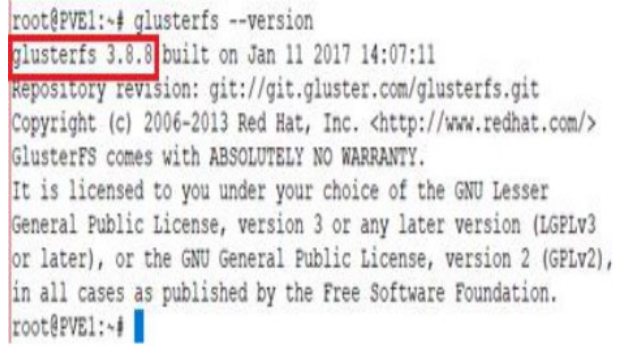

Gambar 5. Hasil instalasi dan konfigurasi Storage GlusterFS Pada PVE 1 \& PVE 2
Hasil installasi dan konfigurasi IP, DNS, Default Route, Network Address Translation (NAT)dan DHCP pada RouterMikrotik.

\begin{tabular}{|c|c|c|c|c|c|c|}
\hline \multicolumn{6}{|c|}{ Address List } & $\square x$ \\
\hline 4 & 5 & $\infty$ & 8 & 20 & $\nabla$ & Find \\
\hline & \multicolumn{4}{|c|}{ Address } & Network & Interface $\boldsymbol{\nabla}$ \\
\hline & \multicolumn{4}{|c|}{ 荬192.168.1.254/24 } & 192.168 .1 .0 & Proxmox \\
\hline & \multicolumn{4}{|c|}{ 茴192.168.100.1/24 } & 192.168 .100 .0 & Client \\
\hline D & \multicolumn{4}{|c|}{ 色192.168.149.136/24 } & 192.168 .149 .0 & Intemet \\
\hline
\end{tabular}

Gambar 6. Hasil Instalasi dan konfigurasi IP pada Interface Router Mikrotik

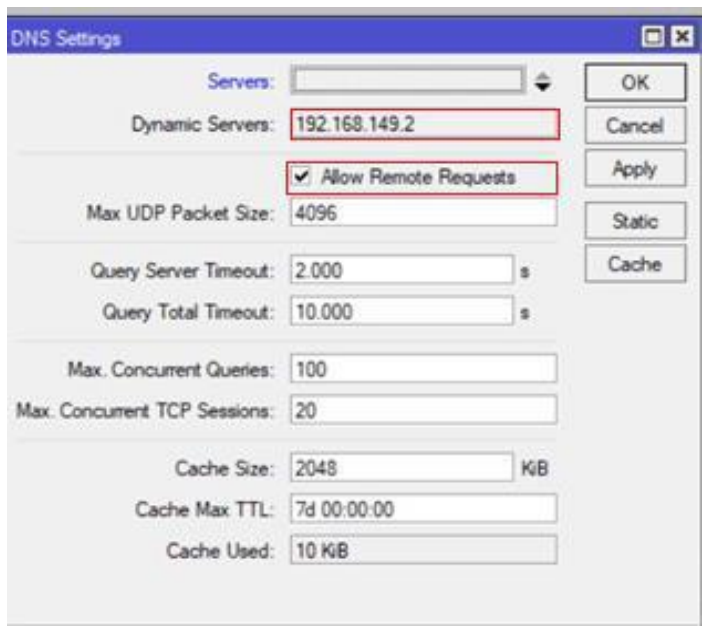

Gambar 7. Hasil Konfigurasi DNS pada Router Mikrotik.

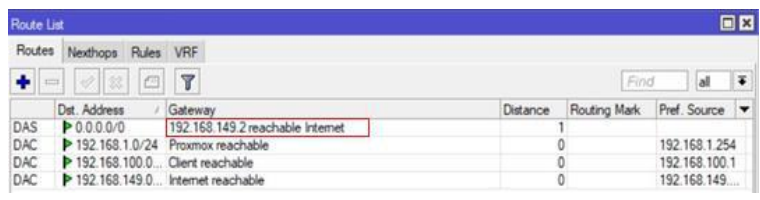

Gambar 8. Hasil Konfigurasi Default Route pada Router Mikrotik

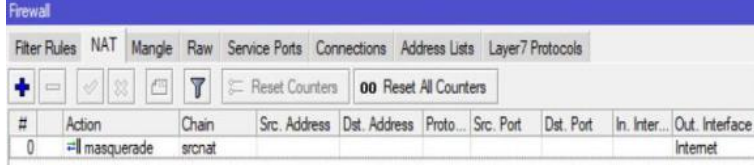

Gambar 9. Hasil Konfigurasi NAT pada Router Mikrotik

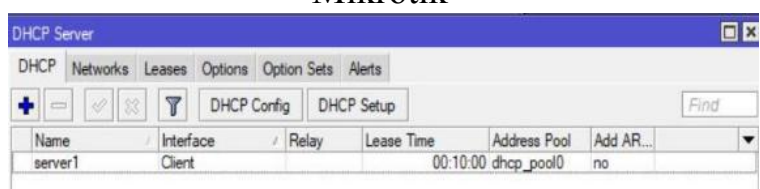

Gambar 10. Hasil Konfigurasi DHCP Pada Router Mikrotik 
Hasil konfigurasi pengalamatan IP PC client, seperti terlihat pada gambar 10 .

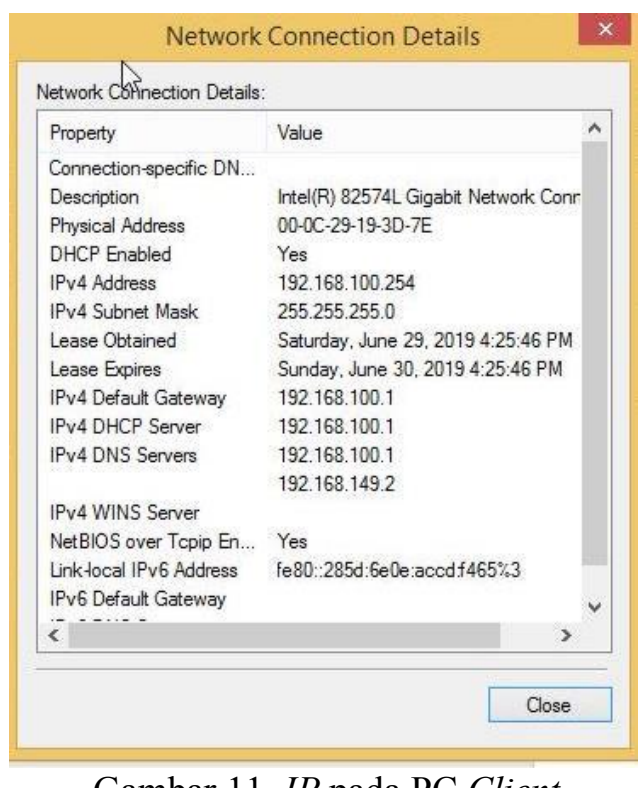

Gambar 11. IP pada PC Client

\section{Hasil Ujicoba}

Terdapat 8 (delapan) skenario ujicoba yang diterapkan pada penelitian ini adalah Instalasi Proxmox VE dengan GlusterFS,Pembuatan LXC dan VMStorage pada GlusterFS, Live Migration,Instalasi Tools Iozone, PengujianReplikasi File dan Pengujian write,re-write, read pada server PVE dengan menggunakan tools I/Ozone.

a. Skenario Integrasi GlusterFS Storage

Pada proses integrasi GlusterFS storage meliputi beberapa tahapan yang dilakukan. Penambahan GlusterFS storage ini dilakukan melalui antarmuka Proxmox VE berbasis web yang dapat diakses melalui alamat https://192.168.1.1:8006. Terdapat 6 (enam) parameter yang harus dikonfigurasi pada kotak dialog Add: GlusterFS.

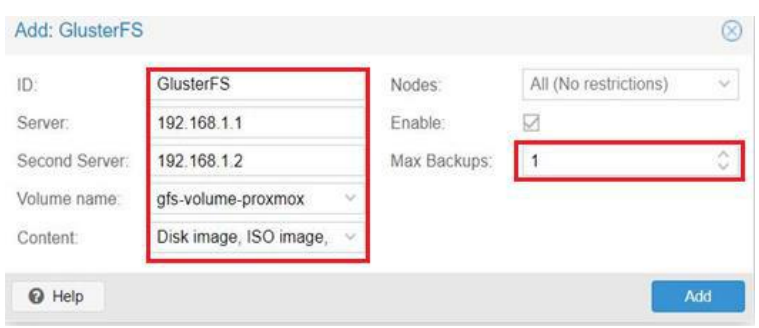

Gambar 12. Menambahkan Storage dengan nama GlusterFS di Proxmox VE
Adapun maksud dari setiap parameter pada kotak dialog tersebut adalah sebagai berikut :

1. ID : digunakan untuk menentukan identitas dari disk storage, yaitu "GlusterFS"

2. Server : digunakan untuk memilih server yang akan dijadikan server utama, yaitu "192.168.1.1"

3. Second-Server : digunakan untuk memilih server cadangan atau server kedua, yaitu "192.168.1.2"

4. Volume-Name : digunakan untuk menentukan identitas dari volume, dalam hal ini pembuatan nama volume harus sesuai dengan nama volume yang telah dibuat pada server PVE1 dan PVE2, yaitu "gfs-volume-proxmox"

5. Content : digunakan untuk menentukan jenis konten yang akan disimpan di disk storage glusterfs yaitu Disk Image, ISO Image, dan Container Template

6. Max Backups : digunakan untuk menentukan jumlah maksimal backups, yaitu " 1 "

Setelah selesai menambahkan storage maka akan muncul tampilan seperti gambar 13 dibawah berikut ini.

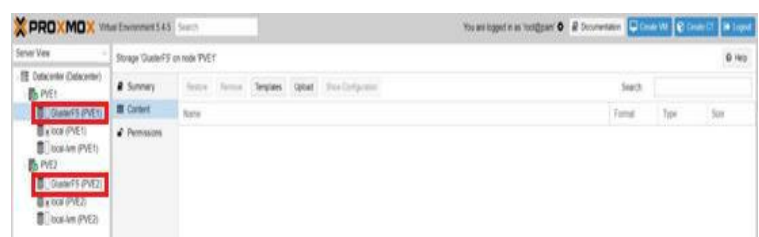

Gambar 13. Tampilan Proxmox yang telah diintegrasikan dengan GlusterFS Storage.

b. Skenario Pembuatan VM pada GlusterFS

Management VM yang dilakukan terdiri dari 2 (dua) skenario yaitu pembuatan VM dan pengaksesan VM yang telah dibuat. Pembuatan VM menggunakan sistem operasi debian-9.8.0 yang dilakukan instalasi pada server storage GlusterFS melalui Proxmox VE.

Hasil pembuatan VM Debian di server PVE1 pada server storage GlusteFS dapat diverifikasi melalui menu PVE1 pada panel Resource Tree dan mengakses menu Search dari panel Content, seperti terlihat pada gambar 14. 


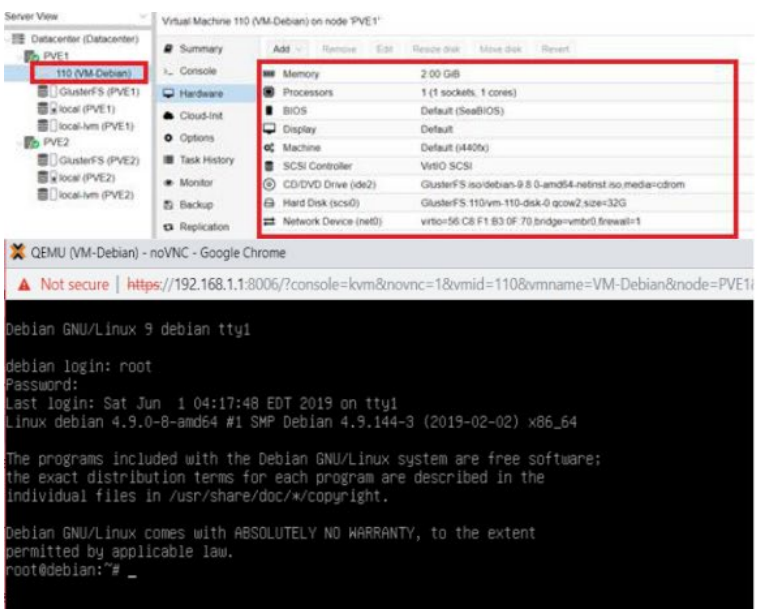

Gambar 14. Hasil PembuatanVM pada Storage GlusterFS.

c. Skenario Pembuatan LXC Container (CT) pada GlusterFS

Manajemen CT yang dilakukan terdiri dari 2 (dua) skenario yaitu pembuatan $\mathrm{CT}$ dan pengaksesan CT yang telah dibuat. Pembuatan CT menggunakan sistem operasi debian versi 8.0 dilakukan pada server storage GlusterFS melalui web Proxmox VE.

Tahapan awal yang dilakukan untuk membuat LXC Container (CT) dari sistem operasi debian-8.0-x86_64.tar di server storage GlusterFS melalui Proxmox VE adalah dengan menekan tombol Create CT pada bagian header dari web administrasi Proxmox VE.

Hasil pembuatan LXC Container (CT) pada GlusterFS Storage.

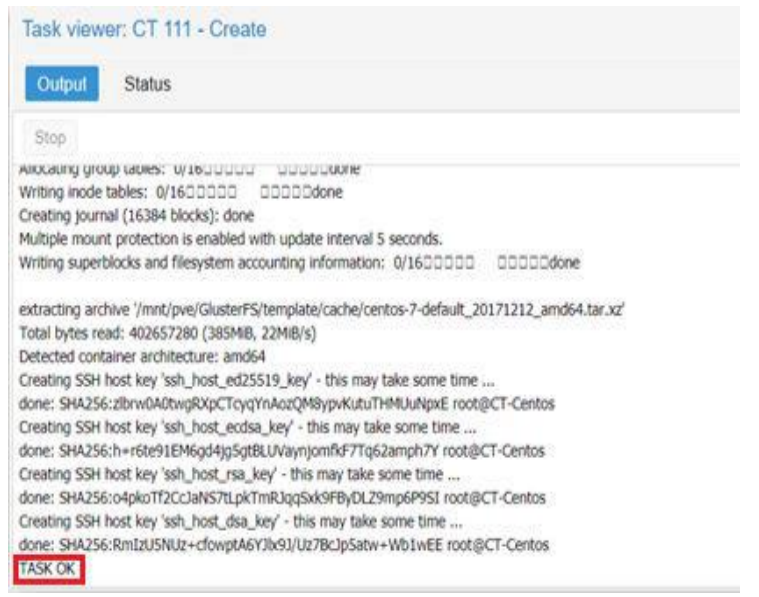

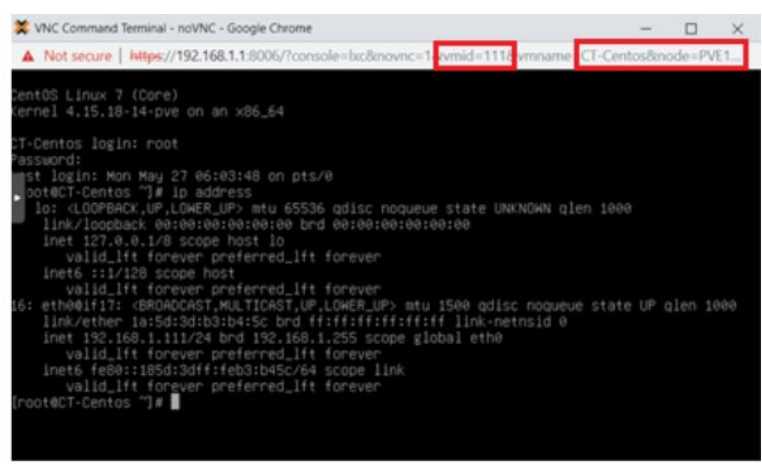

Gambar 15. Hasil pembuatan LXC Container (CT) pada GlusterFS Storage.

d. Skenario Live Migration VM

Skenario ini dilakukan untuk perpindahan VM dengan fitur live migration pada host cluster proxmox dari server PVE1 ke PVE2 dan sebaliknya dari $P V E 2$ ke $P V E 1$. Proses Migrate VM yang berada pada server PVE1 ke PVE2.

Terlihat hasil proses Live Migration pada VM yang ada pada server PVE1 ke server $P V E 2$. Selanjutnya akan tampil kotak dialog Task Viewer : VM 110 Migrate yang menunjukkan output dari proses migrasi, seperti terlihat pada gambar 15 .

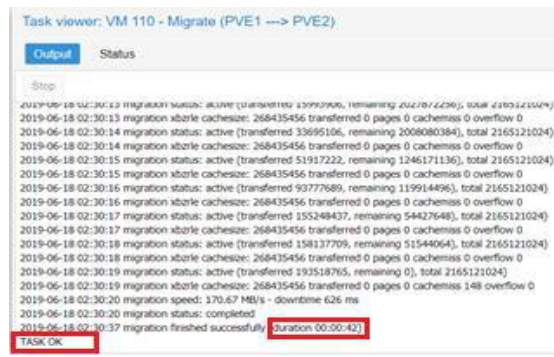

Gambar 15. Hasil Live Migration VMdariPVE1 ke PVE2

\section{e. Skenario Live Migration CT}

Skenario ini dilakukan untuk perpindahan CT dengan fitur live migration pada host cluster proxmox dari server PVE2 ke PVE1 dan sebaliknya dari $P V E 1$ ke $P V E 2$.

Proses Migrate CT yang berada pada server PVE2 ke PVE1.

Terlihat proses Live Migration pada CT yang ada pada server PVE2 ke server PVE1, dengan Mode : Restart Mode yaitu Container akan melakukan shutdown otomatis ketika melakukan proses migrasi CT dan akan menyala kembali ketika CT sudah berada pada server tujuan migrate yaitu PVE1. Selanjutnya akan tampil kotak dialog Task Viewer : CT 100 
Migrate yang menunjukkan output dari proses migrasi, seperti terlihat pada gambar 16 .

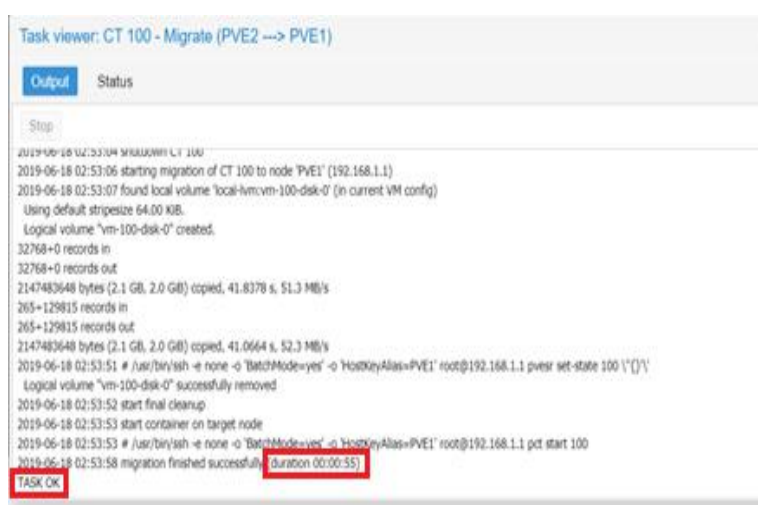

Gambar 16. Hasil Live Migration CT dari server PVE2 ke PVE1

f. Instalasi tools pengujian Iozone

Pada proses instalasi Iozone tolls diperlukan proses update dan upgrade terlbih dahulu pada server PVE(PVE1) dengan menggunakan perintah :

\#apt-get update

\#apt-get dist-upgrade

Setelah itu lakukan proses instalasi paket iozone secara online dengan perintah : \#wget

http://www.iozone.org/src/current/iozone3 394.t ar

\#tar-xf iozone3_434.tar

\#cd./iozone3_434/src/current

Hasil verifikasi dari instalasi Iozone pada server PVE1, terlihat seperti gambar 17.

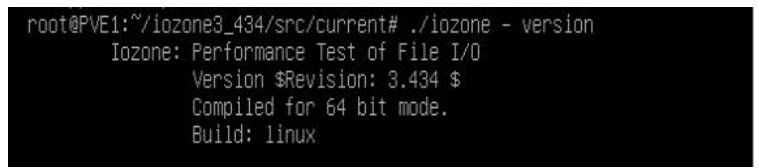

Gambar 17. Hasil Instalasi Tools Iozone

\section{g. Skenario Pengujian Replikasi File}

Pada tahapan ini dilakukan pengujian dengan mengupload file pada storage Glusterfs yang berada di server PVE 1 yang kemudian secara otomatis akan di replikasi ke storage Glusterfs yang berada di server PVE 2 begitupun sebaliknya. Tahapan yang digunakan untuk pembuatan Replikasi file pada server storage GlusterFS adalah diawali dengan menekan tombol Upload pada bagian header dari Proxmox VE.

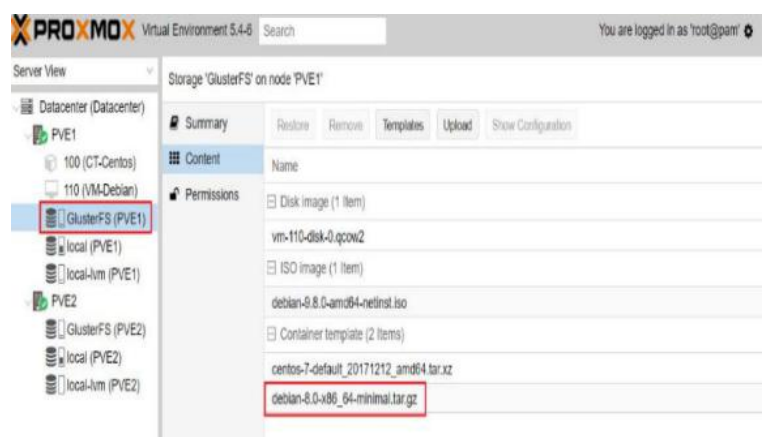

Gambar 18. Replikasi File padaStorage GlusterFSdi PVE1.

h. Skenario Pengujian Write, Re-write dan Read

Pada tahapan ini dilakukan pengujian pada server PVE1 dengan menggunakan tools Iozone, untuk mententukan kecepatan dari read, write dan re-write file pada server tersebut.

Hasil pengujian Write, Re-Write dan Read, seperti terlihat pada gambar 19.

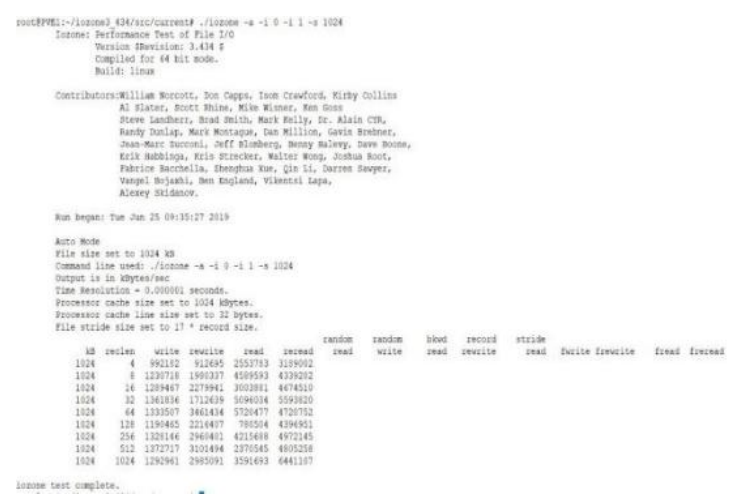

Gambar 19. Hasil pengujian Write, Re-Write dan Read.

\section{Analisa Hasil Ujicoba}

a. Hasil Analisa Management Storage

1) Proxmox VE cluster berhasil di integrasikan dengan GlusterFS Storage dan berdasarkan skenario management Storage yang melakukan pembuatan LXC Container (CT) dan Virtual Machine (VM) yang penyimpanannya berada pada GlusterFS storage, dengan ketentuan $L X C$ dengan $I D$ 111 dan VM ID 110. Kemudian rincian dari penggunaan server storage GlusterFS sesudah pembuatan VM dan CT pada 
storage tersebut yaitu $8,37 \%$ dari $(1.25 \mathrm{GiB}$ of $14.99 \mathrm{GiB}$ ).

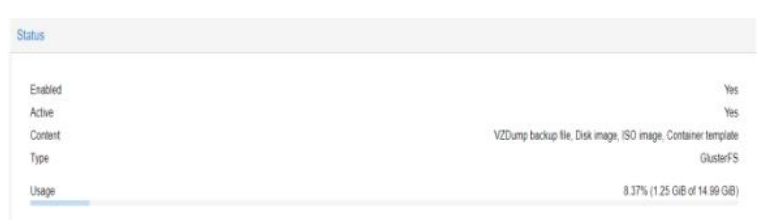

Gambar 20. Hasil Management Stroge Proxmox VE cluster berhasil di integrasikan dengan

\section{GlusterFS Storage}

2) Hasil analisa yang didapatkan dalam management VM dan CT baik VM dan CT tersebut masih aktif atau VM dan CT tersebut sudah tidak aktif adalah sebagai berikut, ketika VM ID 110 dan CT ID 111 masih aktif, maka pada server Proxmox VE terlihat beberapa penggunaan yang meliputi penggunaan CPU $8 \%$ dari (2 CPU), penggunaan memory $69 \%$ dari $(2,02 \mathrm{GiB}$ of $2.94 \mathrm{GiB})$ serta penggunaan storage $18 \%$ dari $(5,98 \mathrm{GiB}$ of $32.46 \mathrm{GiB})$.

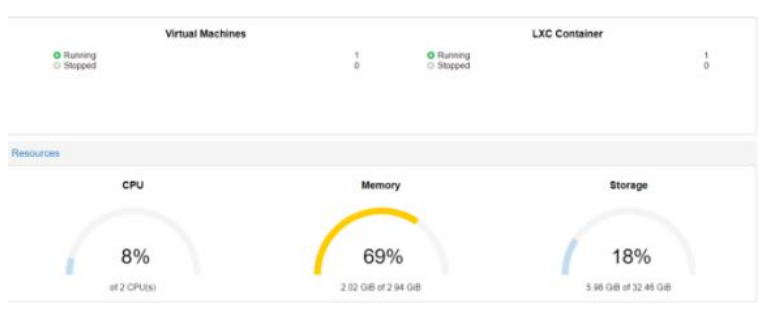

Gambar 21. Hasil Management Stroge Management VM dan CT Masih Aktif

Ketika VM dan CT sudah tidak aktif, maka pada server Proxmox VE terlihat beberapa penggunaan yang meliputi penggunaan CPU 3\% dari (2 CPU), penggunaan memory $47 \%$ dari $(1,93 \% \mathrm{GiB}$ of $2.94 \mathrm{GiB})$. Dari kedua percobaan antara VM dan CT aktif dan tidak aktif dapat disimpulkan bahwa ketika VM dan CT sedang aktif maka untuk penggunaan Memory dan $C P U$ meningkat dibandingkan ketika VM dan CT sedang tidak aktif. Sedangkan pada bagian storage tetap pada angka $18 \%$.

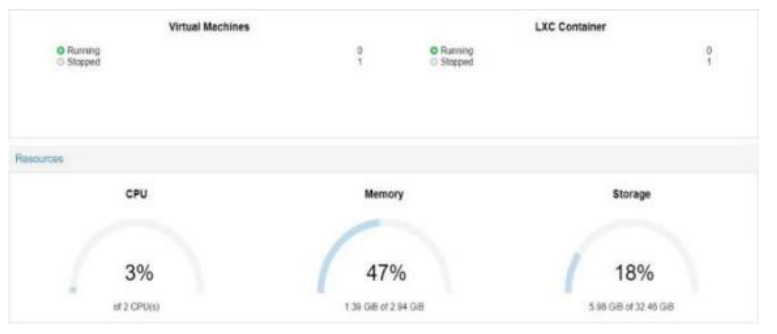

Gambar 22. Hasil Management Stroge Management VM dan CT Tidak Aktif

b. Analisa Live Migration

Hasil analisa yang diperoleh dari proses live migration $V M$ dan $C T$ dengan menggunakan fitur bulk migrate pada Proxmox VE dari server PVE1 ke PVE2 dan sebaliknya dari server PVE2 ke PVE1 lama waktu pemindahan yang dilakukan 5 (lima) kali percobaan terlihat seperti tabel berikut.

Tabel 4. Nilai Waktu Migrasi.

\begin{tabular}{|c|c|c|}
\hline \multirow{3}{*}{ Percobaan } & $\begin{array}{l}\text { PVE 1 Ke PVE } \\
2\end{array}$ & $\begin{array}{c}\text { PVE 2 ke } \\
\text { PVE 1 }\end{array}$ \\
\cline { 2 - 3 } & Waktu Migrasi & $\begin{array}{c}\text { Waktu } \\
\text { Migrasi }\end{array}$ \\
\hline 1 & 45 detik & 60 detik \\
\hline 2 & 45 detik & 55 detik \\
\hline 3 & 42 detik & 53 detik \\
\hline 4 & 50 detik & 59 detik \\
\hline 5 & 47 detik & 56 detik \\
\hline Rata-rata & 45,8 detik & 56,6 detik \\
\hline
\end{tabular}

1) Nilai rata-rata dari perpindahan VM dan $C T$ dengan menggunakan fitur bulk migrate dari server PVE1 ke PVE2 lokasi penyimpanan menggunakan GlusterFS storage dari percobaan pertama sampai kelima rata-rata waktu migrasi yang dibutuhkan adalah 45,8 detik dengan itu dapat disimpulkan bahwa perpindahan dengan live migration tanpa mematikan server guest dalam proses perpindahan dapat dilakukan.

2) Nilai rata-rata perpindahan VM dan CT dengan menggunakan fitur bulk migrate dari server PVE2 ke PVE1 lokasi penyimpanan GlusterFS storage dari percobaan pertama sampai kelima rata-rata waktu migrasi 56,6 detik dengan itu dapat disimpulkan bahwa perpindahan dengan live migration tanpa mematikan server 
guest dalam perpindahan, tidak ada perbedaan waktu yang jauh dari hasil tabel tersebut.

\section{c. Analisa pengujian Write, Re-write dan}

\section{Read}

Pada hasil analisa pengujian write, rewrite dan read pada server Proxmox yang telah diintegrasikan dengan storage GlusterFS akan dilakukan percobaan sebanyak 5 kali dengan menggunakan ukuran file $1 \mathrm{MB}, 10 \mathrm{MB}$, dan $100 \mathrm{MB}$.

1) Nilai Pengujian Write, Re-write dan Read dalam $1 \mathrm{Mb}$

Pada pengujian file size $1 \mathrm{MB}$ menghasilkan nilai rata-rata pengujian Writesebesar $1123438,936 \mathrm{~kb} / \mathbf{s}, \boldsymbol{R}$-writesebesar

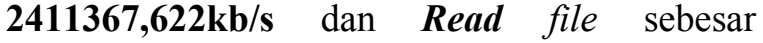
$4276392,732 \mathrm{~kb} / \mathbf{s}$, seperti terlihat pada tabel 5 .

Tabel 5. Pengujian dengan Ukuran File $1 \mathrm{Mb}$

\begin{tabular}{|c|l|l|l|}
\hline $\begin{array}{c}\text { Perco } \\
\text { baan }\end{array}$ & \multicolumn{3}{|c|}{$1 \mathrm{Mb}$} \\
\hline & Write & Re-write & Read \\
\hline $\mathbf{1}$ & 1265777,67 & $\begin{array}{l}2401159,8 \\
9\end{array}$ & $\begin{array}{l}3546910,8 \\
9\end{array}$ \\
\hline $\mathbf{2}$ & 1227346,56 & $\begin{array}{l}2388699,1 \\
1\end{array}$ & $\begin{array}{l}4145302,4 \\
4\end{array}$ \\
\hline $\mathbf{3}$ & 1007527,78 & $\begin{array}{l}2500212,7 \\
8\end{array}$ & $\begin{array}{l}4359250,3 \\
3\end{array}$ \\
\hline $\mathbf{4}$ & 1193173,67 & $\begin{array}{l}2517712,2 \\
2\end{array}$ & $\begin{array}{l}4544326,6 \\
7\end{array}$ \\
\hline $\mathbf{5}$ & 923369 & $\begin{array}{l}2249054,2 \\
2\end{array}$ & $\begin{array}{l}4786173,3 \\
3\end{array}$ \\
\hline $\begin{array}{c}\text { Rata- } \\
\text { rata }\end{array}$ & 1123438,936 & $\begin{array}{l}2411367,6 \\
22\end{array}$ & $\begin{array}{l}4276392,7 \\
32\end{array}$ \\
\hline
\end{tabular}

Untuk mendapatkan hasil yang maksimal, maka hasil dari pengujian file dilakukan dengan membuat grafik rata-rata yang menunjukkan kecepatan Read lebih tinggi dibandingkan Write dan Re-write dengan angka hampir mencapai $5000,000 \mathrm{~kb} / \mathrm{s}$ dimana percobaan 6 (enam) merupakan hasil rata-rata dari 5 (lima) percobaan, seperti terlihat pada gambar 20 .

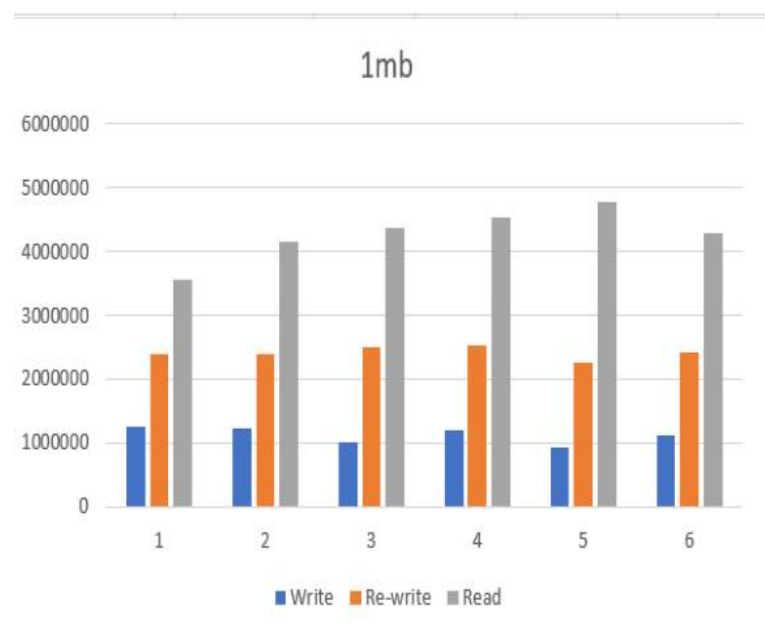

Gambar 23. Grafik Pengujian Ukuran File 1MB

2) Nilai Pengujian Write, Re-write dan Read dalam $10 \mathrm{Mb}$

Padapengujianfilesize 10MB

menghasilkan nilai rata-rata pengujian Write sebesar $1452871,95 \mathrm{~kb} / \mathbf{s}, \boldsymbol{R}$-write file sebesar $3447706,95 \mathrm{~kb} / \mathrm{s}$ dan Read file sebesar

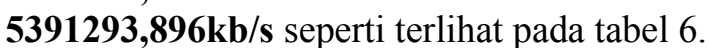

Tabel 6. Pengujian dengan Ukuran File $10 \mathrm{Mb}$

\begin{tabular}{|c|l|l|l|}
\hline $\begin{array}{l}\text { Percoba } \\
\text { an }\end{array}$ & \multicolumn{3}{|c|}{$10 \mathrm{Mb}$} \\
\hline & Write & Re-write & Read \\
\hline $\mathbf{1}$ & $\begin{array}{l}1300586, \\
3\end{array}$ & $\begin{array}{l}3050218, \\
3\end{array}$ & 5003469,6 \\
\hline $\mathbf{2}$ & $\begin{array}{l}2248590, \\
5\end{array}$ & $\begin{array}{l}5256319, \\
3\end{array}$ & 4988738,1 \\
\hline $\mathbf{3}$ & $\begin{array}{l}1284853, \\
3\end{array}$ & $\begin{array}{l}2958848, \\
1\end{array}$ & 4904337,8 \\
\hline $\mathbf{4}$ & 1232106 & $\begin{array}{l}2946473, \\
3\end{array}$ & 5090632,6 \\
\hline $\mathbf{5}$ & $\begin{array}{l}1198223, \\
67\end{array}$ & $\begin{array}{l}3026675, \\
75\end{array}$ & 4809040,8 \\
\hline $\begin{array}{l}\text { Rata- } \\
\text { rata }\end{array}$ & $\begin{array}{l}1452871, \\
95\end{array}$ & $\begin{array}{l}3447706, \\
95\end{array}$ & $\begin{array}{l}5391239,8 \\
96\end{array}$ \\
\hline
\end{tabular}

Untuk mendapatkan hasil yang maksimal, maka hasil dari pengujian file dilakukan dengan membuat grafik rata-rata yang menunjukkan kecepatan Read lebih tinggi dibandingkan Write dan Re-write dengan angka kurang dari $6000,000 \mathrm{~kb} / \mathrm{s}$, seperti terlihat pada gambar 21 . 


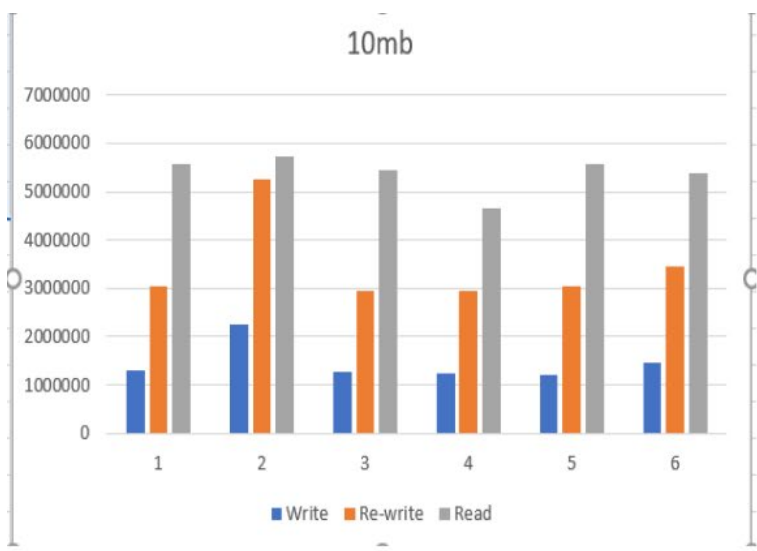

Gambar 24. Grafik Pengujian Ukuran File 10 MB

3) Nilai Pengujian Write, Re-write dan Read dalam $100 \mathrm{Mb}$

Pada pengujian ukuran file size $100 \mathrm{Mb}$ menghasilkan nilai rata-rata pengujian Write sebesar $406513,446 \mathrm{~kb} / \mathrm{s}$, Re-write file sebesar $466901,632 \mathrm{~kb} / \mathrm{s}$ dan Read file sebesar

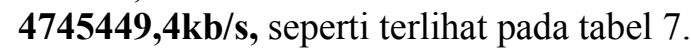

Tabel 7. Tabel Pengujian dengan Ukuran File $100 \mathrm{Mb}$

\begin{tabular}{|c|c|c|c|}
\hline $\begin{array}{l}\text { Perco } \\
\text { baan }\end{array}$ & \multicolumn{3}{|c|}{$\mathbf{1 0 0}$ Mb } \\
\hline & Write & Re-write & Read \\
\hline $\mathbf{1}$ & 420900,15 & 517298,69 & 4330292 \\
\hline $\mathbf{2}$ & 428257,69 & 471071,08 & 4646784 \\
\hline $\mathbf{3}$ & 413899,31 & 449259,08 & 4460655 \\
\hline $\mathbf{4}$ & 414488,23 & 456448,77 & 5865143 \\
\hline $\mathbf{5}$ & 355021,85 & 440430,54 & 4424373 \\
\hline $\begin{array}{l}\text { Rata- } \\
\text { rata }\end{array}$ & 406513,446 & 466901,632 & 4745449,4 \\
\hline
\end{tabular}

Untuk mendapatkan hasil yang maksimal, maka hasil dari pengujian file dilakukan dengan membuat grafik rata-rata yang menunjukkan kecepatan Read file yang terpaut cukup jauh dengan Write dan Rewrite, seperti terlihat pada gambar 22 .

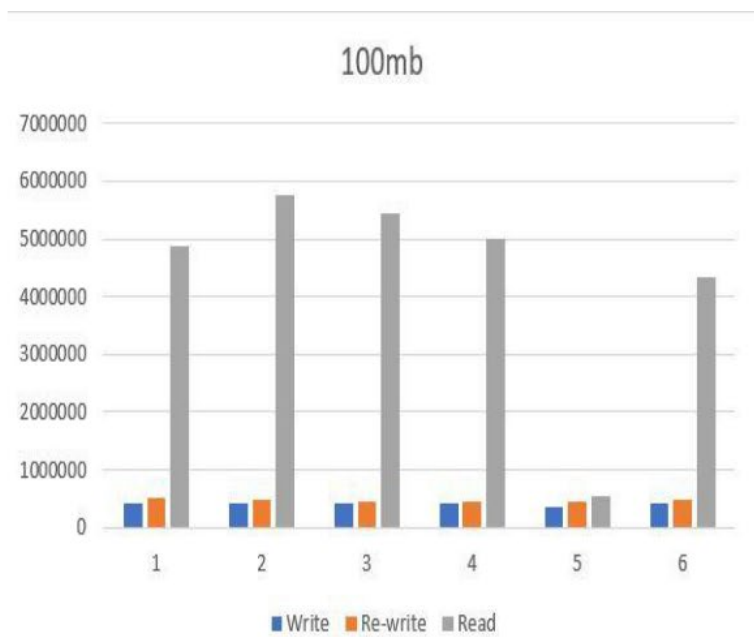

Gambar 25. Grafik Pengujian Ukuran File 100 MB

\section{SIMPULAN DAN SARAN \\ 1. Kesimpulan}

Adapun kesimpulan yang dapat diambil berdasarkan pada hasil installasi dan konfigurasi serta ujicoba yang telah dilakukan sebagai berikut:

1. GlusterFS pada operasional Read file diperoleh hasil rata-rata throughput lebih tinggi $3222544209 \mathrm{~kb} / \mathrm{s}$ dibandingkan dengan Write, dan Re-write pada variasi pengukuran file $1 \mathrm{mb}, 10 \mathrm{mb}$ dan $100 \mathrm{mb}$.

2. Waktu eksekusi migrasi dari PVE1 ke PVE2 selama 45,8 detik, sedangkan waktu yang dibutuhkan eksekusi migrasi dari PVE2 ke PVE1 selama 56,6 detik masingmasing 5 kali percobaan pengiriman file.

3. Sistem PVE cluster dan GlusterFS storage cluster dapat dibangun dengan menggunakan 2 (dua) node yang sama sehingga setiap node menjadi anggota dari 1 (satu) cluster.

4. Setiap data yang diupload pada GlusterFS storage yang berada pada PVE 1 akan di replikasi ke PVE 2 begitu pun sebaliknya.

5. Manajemen storage GlusterFS seperti pembuatan VM dan LXC dapat dilakukan pada PVE browser.

6. Maintenance node dari PVE cluster dan GlusterFS storage cluster dapat dilakukan dengan memanfaatkan fitur live migration dari satu node ke node lainnya dalam kondisi online maupun offline. 


\section{Saran}

Adapun saran-saran untuk pengembangan

lebih lanjut skripsi ini adalah sebagai berikut:

1. Ujicoba menggunakan spesifikasi computer dengan processor, memory dan hardisk yang lebih tinggi sehingga scenario pengujian yang dilakukan lebih variatif.

2. Melakukan pengujian scenario dengan skala laboratorium.

3. Menggunakan node terpisah untuk membentukProxmox VE cluster dan GlusterFSstorage cluster.

4. Percobaan live migration dilakukan dengan menggunakan jumlah VM yang lebih banyak.

5. Menganalisa unjuk kerja dari PVEcluster yang diintegrasikan dengan Network Attach Storage (NAS) selain GlusterFS

\section{UCAPAN TERIMA KASIH}

Pada kesempatan ini penulis menyampaikan penghargaan dan penghormatan kepada semua pihak yang telah membantu dan menyelesaikan penelitian ini, ucapan terima kasih disampaikan kepada :

1. Rektor Universitas Bumigora Mataram yang telah mendukung dan memberikan motivasi dalam penyelesaian penelitian ini.

2. Kepala LP2M Universitas Bumigora Mataram yang selalu menyampaikan informasi terkait penelitian dan membantu dalam publikasi

3. Bapak/Ibu dosen Universitas Bumigora Mataram yang telah mendukung dan membantu dalam penyelesaian penelitian ini.

\section{REFERENSI}

[1] P. Ilmiah, A. D. Albar, P. S. Informatika, F. Komunikasi, D. A. N. Informatika, and U. M. Surakarta, "Disaster recovery dengan proxmox ha cluster dan freenas untuk menambah availability server," 2016.

[2] Y. R. Adi, O. D. Nurhayati, and E. D. Widianto, "Perancangan Sistem Cluster Server untuk Jaminan Ketersediaan Layanan Tinggi pada Lingkungan Virtual," J. Nas. Tek. Elektro dan Teknol.
Inf., vol. 5, no. 2, 2016.

[3] W. Paulus Nanda, "Automatic File Replication Cluster High-Availability Storage Dengan Menggunakan GlusterFS Artikel Ilmiah Peneliti: Program Studi Teknik Informatika Fakultas Teknologi Informasi Universitas Kristen SatyaWacana Januari 2014 Automatic File Replication Clust," no. 672007323, 2014.

[4] M. I. Syafi, A. Bhawiyuga, and M. Data, "Analisis Perbandingan Kinerja File System GlusterFS dan HDFS dengan SkenarioDistribusiStripeddan Replicated," J. Pengemb. Teknol. Inf. dan Ilmu Komput. Univ. Brawijaya, vol. 3, no. 1, pp. 212-219, 2019.

[5] N. D. S, R. Suhatman, and I. Muslim, "Implementasi High Availability Web ServerpadaCloudComputing

Menggunakan Pacemaker," Semin. Nas. Teknol. Informasi, Komun. dan Ind. (SNTIKI-10, no. November, pp. 268-275, 2018.

[6] F. Mintrasih, T. Rosyadi, and F. Nurachman, "ANALISIS KINERJA VIRTUALISAS SERVER MENGGUNAKAN PROXMOX VE PADADISHUBKOMINFO SUMATERA SELATAN Vredi," vol. 3, no. 1, pp. 27-36, 2010.

[7] Arfriandi, "Perancangan, Implementasi, dan Analisis Kinerja Virtualisasi MenggunakanProxmox, Vmware ESX,dan Openstack," J. Teknol., vol. 5 nomor 2, pp. 182-191, 2012.

[8] Y. Afrianto and A. H. Hendrawan, "Implementasi Data Center Untuk Penempatan Host Server Berbasis Private Cloud Computing," Krea-Tif, vol. 7, no. 1, p. 50, 2019. 